\title{
RESÚMENES DE TESIS: MAESTRÍA EN DIDÁCTICA DE LAS CIENCIAS EXPERIMENTALES
}

\section{Los contenidos actitudinales en la trama formativa de los residentes del Profesorado de Biología y su implementación en las prácticas áulicas}

\author{
Mónica Francisca Eceiza \\ monicaeceiza@hotmail.com \\ Director: Dr. Aníbal Bar \\ Lugar de realización: Villa Ángela, Chaco \\ Fecha de defensa: 30 de mayo de 2018
}

La presente tesis, Los contenidos actitudinales en la trama formativa de los residentes del profesorado de Biología y su implementación en las prácticas áulicas, cuestiona si la formación docente promueve en los futuros profesores el desarrollo de estrategias para la enseñanza de contenidos actitudinales relacionados con el aprendizaje de las ciencias. En tal sentido se plantea como Objetivo General reconstruir la trama formativa de un grupo de residentes de dicho Profesorado en relación con la enseñanza de los contenidos actitudinales. La Metodología, de carácter cualitativo, transita tres formas de indagación: una, se centra en la información recogida de los documentos que encuadran la práctica docente; la segunda emerge de los discursos de los actores, y la tercera, relevada a través de un dispositivo de intervención.

Este estudio muestra que existe un desfase entre el decir y el hacer durante las etapas de las prácticas de los residentes del profesorado mencionado. La organización didáctica de las clases (estrategias y secuencia de actividades) se basa fuertemente en contenidos conceptuales. Las actitudes que se enuncian en las planificaciones son de carácter transversal (por ejemplo: el respeto, la tolerancia, la responsabilidad y otras) en desmedro de las específicas referidas a la construcción del conocimiento científico que permitirían el desarrollo de operaciones cognitivas, como el pensamiento crítico.

Palabras claves: actitud, contenido actitudinal, pensamiento crítico. 
The contained attitudinal training plot of the residents of the Faculty of biology and its implementation in the classroom practices.

This thesis, the contained attitudinal training plot of the residents of the Faculty of biology and its implementation in the classroom practices, questions whether teacher training promotes future teachers in the development of strategies for the teaching content attitude related to the learning of science. In this regard arises as General objective reconstruct the plot of a group of residents of the teaching staff in relation to the teaching of the contents attitudinal training. The methodology, qualitative, passes three forms of inquiry: a, focuses on information collected from documents that fit the teaching practice; the second emerges from the speeches of actors, and the third, relieved through an intervention. This study shows that there is a gap between the saying and doing during the stages of the residents of the mentioned faculty practices. The didactic organization of kinds (sequence of activities and strategies) is strongly based on conceptual content. Attitudes that are set out in the schedules are cross-cutting (for example: respect, tolerance, responsibility and others) at the expense of those specific concerning the construction of scientific knowledge that would enable the development of cognitive operations such as critical thinking.

Key words: attitude, content attitude, critical thinking.

Incidencia del uso de un entorno tecnológico presencial-virtual en los procesos de enseñanza y aprendizaje. Desarrollo de una experiencia en el Profesorado de Biología

María Rosa Venezia

veneziamariarosa@gmail.com

Directora: Dra. Ana Patricia Fabro

Co-Directora: Dra. María del Rosario de la Riestra

Lugar de realización: ISPI № 9028 “Ntra. Sra. del Huerto”. Nivel Superior. Profesorado para la Educación Secundaria en Biología. Rosario. Provincia de Santa Fe. Argentina

Fecha de defensa: 28 de marzo de 2018

Numerosas investigaciones señalan las ventajas del uso de las tecnologías de la información y la comunicación (TIC) para la enseñanza y los aprendizajes de las Ciencias Experimentales. Sobre este punto es necesario tener presente que su incorporación en educación exige un alto grado de responsabilidad para el diseño y evaluación de la propuesta educativa, y un proceso de investigación que monitoree los alcances de la misma. 
Para realizar aportes en torno al tema, este trabajo de tesis tiene como objetivos investigar las posibilidades y limitaciones de la aplicación de un entorno presencial-virtual en los procesos de enseñanza y aprendizaje del tema "Disoluciones" en la asignatura "Química General y Biológica", de primer año, única división, del Profesorado para la Educación Secundaria en Biología del Instituto Superior Particular Incorporado N 9028 “Nuestra Señora del Huerto” de la ciudad de Rosario.

Para tal fin se diseñó un entorno virtual de enseñanza y aprendizaje que complementó la actividad presencial obligatoria de la asignatura durante el año 2013 y se investigó mediante metodologías cuali-cuantitativas sus aportes a los procesos de enseñanza y aprendizaje.

Para la recolección de datos se utilizaron: a) Cuestionarios con preguntas cerradas, formulados antes y después de la intervención didáctica; b) Observación no participante de la intervención didáctica (clases presenciales y actividades llevadas a cabo mediante el entorno virtual); c) Entrevistas semiestructuradas realizadas a los estudiantes luego de la intervención didáctica.

Como resultados de los cuestionarios formulados a los estudiantes en la etapa previa a la intervención didáctica se halló lo siguiente:

- El acceso a materiales tecnológicos y la conectividad en la población estudiada es alta, tanto desde los hogares como desde la institución.

- La utilidad que los estudiantes le asignan a las TIC está en relación con la búsqueda de información, la comunicación y la producción de documentos.

- La resistencia a la incorporación de herramientas tecnológicas es baja, aunque señalan la necesidad de formación para un uso adecuado.

- La formación en herramientas tecnológicas en su mayoría fue adquirida en la escuela secundaria y/o de manera individual, pero su uso durante el nivel educativo anterior fue bajo.

- Las percepciones de los estudiantes en torno a la utilización de TIC son favorables por considerarlas innovadoras, por ofrecer diversidad de herramientas y mayor cantidad de información, al tiempo que manifiestan cierta desconfianza respecto del rol docente, en torno de la confiabilidad de la información y de la posibilidad de acceso a la tecnología.

- Se aprecia que los alumnos tienen preferencia por el material impreso y por la clase presencial por sobre el material digital y la clase virtual, pero sostienen que el abordaje de temas de Química General y Biológica, mediado por TIC puede mejorar su preparación como docentes.

A partir de los instrumentos aplicados durante y en forma posterior a la intervención didáctica se observó lo siguiente:

- La apropiación de conocimientos mediante un entorno presencial-virtual es alta, especialmente en cuanto a la relación teoría-práctica.

- La modalidad posibilitó entender temáticas complejas mediante videos y animaciones. 
- Los estudiantes se implicaron con interés en el aprendizaje del tema, sosteniendo que el acceso al contenido resultó interesante.

- Se presentaron escasas dificultades para el manejo de las tecnologías.

- Los estudiantes insisten con la necesidad de contar con el material impreso, las actividades de laboratorio y la clase previa de intercambio de ideas sobre los conceptos fundamentales del tema en forma presencial.

- Sostienen que el entorno presencial-virtual facilitó el aprendizaje y la incorporación de conocimientos a través de las animaciones, videos explicativos, la elaboración de presentaciones de power point de manera cooperativa como síntesis explicativa del contenido y por el acceso a información variada y abundante sobre el tema.

- Manifestaron un aumento de la motivación por la novedad y variedad, y por la posibilidad de aprendizaje del uso y aplicación de herramientas tecnológicas que los capacita en las competencias necesarias para los docentes, en el marco de la sociedad del conocimiento.

Como resultado de la investigación se concluye que la enseñanza del Tema "Disoluciones" mediante un trabajo conjunto de manera presencial y virtual en un entorno tecnológico, potencia los procesos de enseñanza y de aprendizaje, siendo además valorado positivamente por los estudiantes.

\section{Incidence of the use of a presential-virtual technological environment in the processes of teaching and learning. Development of an experience in the Professor of Biology}

Numerous weekly investigations show the use of ICT for teaching and learning experimental science. To make contributions on the subject, this thesis work aims to investigate the possibilities and limitations of the application of a virtual presence environment in the processes of teaching and learning about the theme "Dissolution" in the term "General and Biological Chemistry" , first year, only division, Professor for the Secondary Education of Biology of the Higher Private Institute Incorporated No. 9028 "Our Lady of the Garden" of the city of Rosario.

For this purpose, a virtual environment of teaching and learning is designed that complements the obligatory present activity of the assignment during the year 2013 and is investigated by means of qualitative and quantitative methodologies in support of the teaching and learning processes.

For the collection of data will be used: a) Questionnaires with closed questions, formulated before and after the didactic intervention; b) Observation in the participant of didactic intervention (present classes and activities carried out through the virtual environment); c) Semi-structured interviews conducted with students from the didactic intervention. 
As a result of the investigation, it is concluded that the theme of the "Disolutions" theme through a set of presential and virtual management through a technological environment, enhances the processes of teaching and learning, although it is positively valued by the students. 